\title{
Ethnic differences in birthweight-related parameters with particular reference to possible maternal nutritional risk factors
}

\author{
R. G. CONDIE \\ M.D., M.R.C.O.G. \\ P. B. TERRY \\ F.R.C.S.E., M.R.C.O.G. \\ Department of Obstetrics and Gynaecology, Dudley Road Hospital, Birmingham B18 7QH
}

\begin{abstract}
Summary
Three birthweight-related parameters were examined in the deliveries occurring from January to July 1982 at Dudley Road Hospital, Birmingham, in 3 major ethnic groups and in relation to possible maternal nutritional risk factors in the European and Indian groups. Ponderal index did not correlate with either mean or 'corrected' birthweight especially in the West Indians.

The 3 maternal nutritional risk factors appeared to be of greater fetal prognostic value in the Indian group than in the European group.
\end{abstract}

KEY WORDS: birthweight, blacks, whites, Asians.

\section{Introduction}

When judging the effects of either an 'inadequate' diet or dietary supplementation in pregnancy with special reference to fetal outcome, birthweight and 'corrected' birthweight are insensitive parameters. Ponderal index should more accurately measure the true nutritional status of the baby (Miller and Hassanein, 1971).

\section{Patients and methods}

At Dudley Road Hospital, 1897 pregnancies from January to July 1982 were analysed by ethnic distribution in the way previously described (Terry, Condie and Settatree, 1980; Terry and Condie, 1981). Europeans were compared with West Indians and Indians, and nutritionally 'at risk' pregnancies were assessed in relation to mean birthweight, 'corrected' birthweight and mean ponderal indexx. Maternal nutritional risk was classified by the following 3 parameters: (a) $50 \mathrm{~kg}$ or less at 20 weeks of gestation; (b) $3 \mathrm{~kg}$ or less weight gain between 20 and 36 weeks;

(c) maternal weight index 20 or less.

The following definitions were employed:

$$
\text { Maternal Weight Index }=\frac{\text { Height }(\mathrm{m})^{2}}{\text { Weight }(\mathbf{k g})}
$$

$$
\text { Ponderal Index }=\frac{\text { Birthweight }(\mathrm{g}) \times 100}{\text { Crown-heel length }(\mathrm{cm})^{3}}
$$

$\begin{aligned} & \text { Mean corrected } \\ & \text { birthweight }\end{aligned}=\Sigma \frac{\text { (Birthweight } \pm \text { correction })}{\text { Number }}$.

Correction was for maternal height and weight, fetal sex, birth order and gestational length using Altman and Coles nomograms (Altman and Coles, 1980; Thomson, Billewicz and Hytten, 1968). The data has been extracted from an ongoing epidemiological study in Dudley Road Hospital. Statistical analysis was by Student's $t$-test.

\section{Results}

The mean birthweight was less in the West Indian and Indian groups when compared with the Europeans $(P<0.001$, Table 1$)$. This difference was less marked in the Indian group when 'correction' was applied $(P<0.05)$, but was accentuated in the West Indians.

The mean ponderal index was lowest in the Indian group $(P<0.001)$. However, the low mean and corrected birthweight in the West Indians was not reflected in a lower mean ponderal index.

In Indian and European mothers who weighed less than $50 \mathrm{~kg}$ at 20 weeks of gestation, the mean and corrected birthweight and the mean ponderal index were lower in the Indians (Table 2$)(P<0.001$ for ponderal index). European mothers in this risk group, despite having a lower mean birthweight, had a higher mean ponderal index than the rest of the Europeans (Table 1 and Table 2), suggesting that low maternal weight in Europeans, unlike the Indians, does not represent an increased risk to the fetus.

In Indian and European mothers who gained less than $3 \mathrm{~kg}$ between 20 and 36 weeks, the mean and corrected birthweights in the Indians were higher, the mean ponderal index being lower. 
TABLE 1. Ethnic differences in birthweight related parameters at Dudley Road Hospital, Birmingham (January-July, 1982) [mean (s.d.)]

\begin{tabular}{lccc}
\hline & Europeans & West Indians & Indians \\
\hline Number & 734 & 280 & 478 \\
Birthweight (g) & $3271(521)$ & $3102^{*}(451)$ & $3063^{*}(468)$ \\
Corrected birthweight (g) & $3187(495)$ & $2993^{*}(440)$ & $3116 \dagger(443)$ \\
Ponderal index & $2.59(0 \cdot 41)$ & $2 \cdot 60(0 \cdot 37)$ & $2 \cdot 51^{*}(0 \cdot 37)$ \\
\hline
\end{tabular}

Differences from European: ${ }^{*} P<0.001 ; \nmid P<0.05$.

TABLE 2. Maternal nutritional risk factors in relation to birthweight related parameters at Dudley Road Hospital, Birmingham (January-July 1982) [mean (s.d.)]

\begin{tabular}{|c|c|c|c|c|c|c|}
\hline & \multicolumn{2}{|c|}{$\begin{array}{l}\text { Less than } 50 \mathrm{~kg} \text { at } \\
20 \text { weeks }\end{array}$} & \multicolumn{2}{|c|}{$\begin{array}{l}\text { Less than } 3 \mathrm{~kg} \text { weight } \\
\text { gain } 20-36 \text { weeks }\end{array}$} & \multicolumn{2}{|c|}{ Weight index $<20 \frac{\mathrm{\sigma}}{\mathrm{O}}$} \\
\hline & Indian & European & Indian & European & Indian & European \\
\hline $\begin{array}{l}\text { Mean birthweight (g) } \\
\text { Mean corrected birthweight (g) } \\
\text { Mean ponderal index } \\
\text { Number }\end{array}$ & $\begin{array}{c}2867(430) \\
3093(425) \\
2 \cdot 44^{*}(0 \cdot 37) \\
129\end{array}$ & $\begin{array}{c}2996(482) \\
3204(496) \\
2 \cdot 64(0 \cdot 39) \\
66\end{array}$ & $\begin{array}{c}3154(424) \\
3171(412) \\
2 \cdot 49(0.35) \\
49\end{array}$ & $\begin{array}{c}3080(447) \\
2999(414) \\
2 \cdot 54(0 \cdot 33) \\
61\end{array}$ & $\begin{array}{c}2839(378) \\
3029(360) \\
2.45(0 \cdot 42) \dagger \\
74\end{array}$ & $\begin{array}{c}2953(506) \text { (హ) } \\
3073(517) \text { ఠి } \\
2.60(0.42) \text { ब } \\
79\end{array}$ \\
\hline
\end{tabular}

Differences from European: ${ }^{*} P<0.001 ; \nmid P<0.05$.

With regard to a weight index of less than 20 , the mean and corrected birthweight, and ponderal index were less in the Indians $(P<0.05$ for ponderal index $)$.

The 3 possible maternal nutritional risk factors were seen to be of greater fetal prognostic value in the Indian group than in the European group.

\section{Discussion}

Interest has recently been focussed on poor nutritional status during pregnancy in our Asian population (Bissenden et al., 1981) and attempts have been made to improve fetal nutrition by maternal dietary supplementation (Veigas et al., 1982a and b). Results are conflicting, however, and it is suggested that future studies would be strengthened by the use of 'corrected' data and ponderal index rather than relying on mean birthweight alone.

\section{Acknowledgment}

Mr P. B. Terry is in receipt of a West Midlands Regional Health Authority research grant.

\section{References}

Altman, D.G. \& Coles, E.C. (1980) Nomograms for pregise determination of birthweight for dates. British Journal of Qbstetrics and Gynaecology, 87, 81.

BisSENDEN, J.G., SCOTT, P.H., King, J., Hallum, J., MansEiliel. H.N. \& WHARTON, B.A. (1981) Anthropometric and biochenical changes during pregnancy in Asian and European mothers Fla light for gestational age babies. British Journal of Obstetrics and Gynaecology, 88, 999.

MILLER, H.C. \& HASSANEIN, K. (1971) Diagnosis of impaired figlal growth in newborn infants. Pediatrics, 48, 511.

TERRY, P.B. \& CONDIE, R.G. (1981) Ethnic differences in perinatal mortality. Postgraduate Medical Journal, 57, 790.

TERRY, P.B., ConDIE, R.G. \& SETTATREE, R.S. (1980) Analysiक्रेंof ethnic differences in perinatal statistics. British Medical Jourhal, 281, 1307.

Thomson, A.M., Billewicz, W.Z. \& HytTen, F.E. (1968) The assessment of fetal growth. Journal of Obstetrics and Gynaecology; British Commonwealth, 75, 903.

Veigas, O.A.C., ScotT, P.H., Cole, T.J., Mansfield, hiN., WhaRTON, P. \& WHARTON, B.A. (1982a) Dietary protein enęgy supplementation of pregnant Asian mothers at Sorrento, Birmingham I. British Medical Journal, 285, 589.

Veigas, O.A.C., Scott, P.H., Cole, T.J., Eaton, P., NeedhAM, P.G. \& WhARTON, B.A. (1982b) Dietary protein energy supplementation of pregnant Asian mothers at Sorrento, BirmingharifII. British Medical Journal, 285, 592. 